\title{
The issue of the conquest of the Kokand Khanate by the Russian Empire is covered by the literature of the Independence period
}

\author{
J.J. Yakobjanov ${ }^{1}$ \\ ${ }^{1}$ The Republic of Uzbekistan Academy of Sciences History Institute base doctoral \\ candidate, Uzbekistan
}

Email:_yakobjanov_j@umail.uz

\begin{abstract}
This paper investigates the issue of the conquest of the Kokand Khanate by the Russian Empire. On this case, materials which used to cover all information by the literature were stated. Independence period mass media and their attention and reaction were analyzed and in conclusion were given to the references to the further research topics.
\end{abstract}

Keywords: Issue, conquest, Kokand, Khanate, Russian Empire, literature, Independence period, mass media.

\section{INTRODUCTION}

Since the second half of the XX century, there have been drastic changes in the evaluation of the political relations between the khanates of Central Asia, including the Kokand Khanate and Russia, especially from the point of view of historiography, the process of the Tsarist Russia's invasion of the Kokand Khanate. If there was an interpretation that until these years the khanates of Central Asia were occupied by Tsarist Russia, then now these territories were trying to prove that they were annexed. Many articles and books have been published and several scientific conferences have also been organized in this regard. It's about published works and conferences.Detailed coverage in ahmadjonov's study.

In Tashkent City in 1959, under the leadership of the Academy of Sciences of the USSR, the Joint Scientific Session of the Academies of Sciences of Uzbekistan, Turkmenistan, Tajikistan and Kyrgyzstan was devoted to the topic "progressive importance of the accession of Central Asia to Russia", and after this conference on the issue of "Russia - Central Asia relationship" began to be

In this case, it was very difficult to objectify the relations between the two countries. Because of the severe censorship set in the era of the Soviets, the historical events ofcolisona would not allow clear illumination. In particular, thanks to censorship, R. on the history of Khanate.Nabiev's work "trace istorii Kokandskogo khanstva" threeraydi.

Therefore, in studies carried out by our historians in these periods, it is possible to see that the Kokand-Russian relations were carefully matched, that in the coverage of diplomatic relations between the two countries, very narrow information was quoted. To such research X.Sadigov and H.It is possible to indicate the candidate dissertations, which were carried out by bobobekovs .

By the 80-90 years of the last century, Uzbek historians in particular, H.Bobobekov argued that the history of the Khanate should be studied objectively on the basis of a new scientific point of view.As a result of his research, the occupation of the khanates of Central Asia by Tsarist Russia was proved on the basis of historical documents. Since 1989 year, when the policy of" restructuring "continued, He was asked" Did Russia conquer Central Asia?"and" Central Asia is annexed to Russia? he has published two articles titled. In these articles it was proved that the Kokand Khanate was conquered by the Russian Empire. 


\section{THEORETICAL BACKGROUND}

In Soviet times, historical events were comprehensively illuminated by the fact that local authors were not used to their manuscripts, local Patriots were described as cowardly and helpless before the invading troops. The fact that in the period of independence, historical hands also began to be used is of great historical and spiritual importance. Therefore

Extensive use of such historical written monuments in the study of Kokand-Russian relations is a modern requirement .

Since 1991, after the independence of the Republic of Uzbekistan, it became possible to study the history of our homeland in a truthful way before historians. As a result of this, the researchers began to objectively collide in the coverage of Kokand-Russia relations.

Of course, the role of the sources written by local historians in generating such scientific conclusions was great in the Re-Publication and study of them in the period of independence of our country. In particular, as a result of the study of the works of Avaz Muhammad Attar, Muhammad Hakimkhon, Muhammad Yunus Toib, Muhammad Solikhocho, Ishaqhon imlat, Mirzo Alim Tashkent, Mulla Alim Mahdum Haji and others, the policy of aggression and violence of the Russian Empire was more openly manifested. Also in their works, the Russian soldiers and officers were described as invaders and were given detailed coverage. In the sources mentioned, their authors are distinguished by the fact that the relations between Kokand and the Russian Empire are illuminated within the framework of the Tsarist Russian invasion. Their data, along with period historians and archival information, help to objectively illuminate the details of events .

\section{LITERATURE REVIEW}

Based on these sources new content and our national ideology y.Qasimov, H.Bobobekov, H.Ziyayev, Sh.Vahidav, B.Babadjanov, V.Ishquvatov, Z.Ilxomav, T.Godkulov, N.In the framework of this problem, a number of scientific works have been published by a number of historians such as Topildiev . As a result of this, along with the denial of the unpleasant thoughts existing in the history of our statehood, it caused a truthful coverage of our history, in particular, the history of the Kokand Khanate.

In Particular, H.In the Ziyoev study, the actions of Mohammed Salih Tashkent in the process of Khanate invasion by the Russian Empire using such sources as "history of jadidayi Tashkent", Mullo Yunusjon Munshi "history of Amir lashkar Alimkul", Avaz Muhammad Attar Huqandi "history of jahonnomai Tashkent", Mullo Alim Mahdumhoji "history of Turkestan" are detailed.

One of the first research works in the years of independence on this problem is y.It was carried out by Kosimov, in which the processes of the conquest of the Khanate by Russia were fully illuminated. It is known that the Russian Empire began the movement of the conquest of Central Asia from Xviiiasr. Pyotr I considered that the control of the territories of present-day Kazakhstan will serve as the main corridor for the capture of Central Asia in the future. Therefore, the capture of Central Asia in the XVIII century of the Russian Empire adjoins Central Asia and builds a total of 46 military fortresses in the territory of Kazakhstan. These fortresses had to function as a military base in the future invasion of Central Asia. Initially, with the capture of the Fortress of Akmaszhid in 1853 year, a road was opened for entry into the inner parts of Central Asia. As a result of the study of the above literature, it can be seen that the Russian Empire again revived in the summer of 1860 due to the stagnation of the Crimean War (1853-1856) in relation to the Kokand Khanate, in particular to Central Asia. As a result of this, the troops of the Rothian Empire occupied the fortification of the knots headed by Colonel TSimmermann on August 26, the Pishpak fortress on September 5, 1860, the Yangikurgun on June 12, 1861, the Aksu, Pishtepa and choldevor fortresses on may 1862, the Steppe fortress on June 8, 1863, the city of Turkistan on June 12, 1864 was got fortification of them.

\section{MAIN PART}

In the literature of the period under study, unlike the literature of the prehistoric period, the Russian Empire began to illuminate as widely as possible the fact that in the implementation of its own policy of conquest, for its own benefit, they thought up all sorts of tricks and cheats, and in some cases, for no reason and no excuse, they conquered the castles It can also be seen that in the literature of this period, the victory of the Kokand Khanate over the Russian invaders was also noted. 
In Particular, H.In his work, Ziyoev gave information about the battle, which won a great victory over the enemy army of the kokandians on July 14, 1864, and then the embassy, which was sent under the leadership of Seversov. According to him, after the victory of The Defenders of Vatan, he became the ambassador of Seversov before Alimkul by the enemy, and Alimkul demanded that he be returned to the Khanate of Avliyoota and Kokand of Turkistan .

The new history of Uzbekistan, published in 2000, is widely covered in the I book, as well as the possible defeat of Russian troops in bat, Pishpak, Chimkent, Tashkent and Ikon .

In addition, the information contained in this content is N.Topildiev's

The first attack on Tashkent began. But the Tashkent people established the protection of the city, and the governor of the city with the kushparvonachi Kipchak navkars settled in the eastern part of the city, the gate of Mirzo Ahmad kushkurgan Akkurgan, The Good Mohammed Afghan yawning Gunner Horde and strongly resisted, general Chernyaev notes that he was forced to return to the Chimkent after being defeated .

Z.Ilhomov's research focuses on the activity of Alimkuli Amirlashkar in the protection of the Kokkan Khanate from the aggression of the Russian empire, unlike other literature, as well as his courage in IQAN, Chimkent and Tashkent mudofaas. The victory of Alimukuli in these battles in turn means the defeat of the Russian troops*.

At the same time, these battles began to be covered in the literature of the period of Independence, when the Russian Empire acted mercilessly. In particular, such cruelty can be seen in the process of occupation of Akmasjid, Chimkent and Tashkent. It can not be said openly in the Soviet literature that he brutally swept the local Patriots. However, there are a lot of archival documents about this, as well as many sources written by local historians.

Not only the Kokand Khanate, but also the processes of the invasion of Tashkent, one of the central cities of Central Asia, are fully covered in the literature of the period under study. In particular, the fact that Russian diplomacy in the occupation of Tashkent acted without subordination to the center, as well as the fact that the city of goyoki was annexed to the empire with its own wishes, is another characteristic aspect of the literature of this period.

In the article"occupation of Tashkent (1865) "published in the" Encyclopedia of Tashkent, " the invasion of Tashkent by Tsarist troops under the command of Chernyaev of the Russian generals is described in detail. In this article it is written that, despite the fact that the Russian government did not officially allow the invasion of Tashkent, on 27 September 1864, Russian troops led by general Chernyaev set out from the chimpanzee to take over Tashkent and shot from the balls, besieging the city.

At the end of the article it is stated that on the morning of June 17, The Tashkent people could not withstand the enemy attack, surrendered, the Tsar's troops invaded Tashkent and established Russian state sovereignty in the city and around it, but general Chernyaev began to march to Tashkent arbitrarily without the permission of the Tsar's government, noting that his

Being attacked by the Russian empire without Tashkent, its occupation leads to a surge of discontent in Europe with respect to the Russian government. This has a particularly negative impact on Russian-British diplomacy. For this reason, genern Chernyaev organized a fraudulent document on behalf of the City Chiefs about voluntary subordination of Goyo Tashkent to the Russian troops in order to justify its occupation. In this "document"it was necessary for the Tashkent people to fully deny the hard battles and the victims given to the city mudofa, and to recognize their submission to the Chernyaev soldiers "voluntarily", the article says .

Sh.Karimov and R.In the book of the shamsutdinovs" during the period of the Russian invasion of Turkistan", it was noted that this letter was forged by Chernyaev and he wanted to sign it using diplomacy .

H.Ziyoev wrote in his monograph titled" The struggle against Russian aggression and domination in Turkestan "that the Russian conquest of Tashkent"led to" protests and riots in the world, especially in England and Turkey". In order to mitigate this situation, general Chernyaev ordered the preparation of the above letter on behalf of the population, collecting urban adults to voluntarily show Tashkent as if it were subordinated to its troops. A group of patriots, who were not included in this letter, were arrested under the order of general Chernyaev. Then general Chernyaev gave the covenant to

* Илхомов 3. Амирлашкар тарихи. Тошкент: Низомий номидаги ТДПУ. 2008. 72-73-бб. 
merchants named Abusaid and Khodikhaja and ordered them to go to St. Petersburg-to the Tsar. This will spread the covenant to foreign countries with the aim of hiding their occupation and eliminating the news of the occupation of Tashkent by Russia in the World Press. Indeed, the Russian Embassy in Turkey often sticks copies of the covenant to the streets, markets and shops of the hotel ${ }^{\dagger}$.

In this way, the Russian emperor issued an official decree in 1866 on the fact that Tashkent was at the disposal of the Russian state. In 1867, the Turkestan Geno-governor's office, which includes the regions of Sirdarya and Ettisuv, was established. The Turkistan governor's office was divided into two districts: Sirdarya, the center of which is Tashkent, and Ettisiye, the center of which is Verniy-Almaota.

At the same time, Tashkent became part of the territory of the Russian state and an important base for establishing the Empire's rule in Central Asia.

Information about the occupation of the Kokand Khanate by Russian troops is also contained in the second volume of a two-volume book "The History of the peoples of Uzbekistan". But from what sources this information was obtained, it is not quoted in the bibos.

In this way, the Russian Empire is gradually realizing its aggressive policy and achieving the conquest of the khanates of Central Asia with all sorts of excuses.

It is known that in August 1866 year an official decree will be issued on the transfer of the Russian emperor to the Russian subordination of Tashkent. In 1867, the Turkestan Geno-governor's office, which includes the regions of Sirdarya and Ettisuv, was established.P.fon-Kaufman is appointed governor of general -. They give him very big rights and raise him to the level of the" Half-King".

\section{DISCUSSIONS}

H.N.Y.In bobobekov's article "bloody traces in our history", the establishment of the Turkestan Genoese governor's office was established in 1867, the chief Genoese-adjutant background K.P.It was noted that Kaufman was appointed, his foreign policy was to keep the khanates at the level of vassal - subordination, without allowing the three independent Uzbek states to unite among themselves. Also, due to the fact that many lands of the Kokand Khanate were occupied, the Russian government sought to conclude a contract with the Khan in order to obtain them official legalization, to create ample opportunities for Russian merchants. To this end, under the leadership of polkovnik Shaufus, the ambassadors were sent and the contract signed by Kaufman was signed by Godoyorxon on February 13, 1868. According to this agreement, it is stated that for Russian merchants to have their own caravanserai in all cities and villages in the Kokand Khanate, it is allowed to appoint representatives of trade, while Kokand merchants are only in cities and villages under the jurisdiction of the Turkestan general-governor, that is, they have such a right on the soil of their homeland, Russian merchants In addition, according to the Treaty of 1868, the Kokand Khan was equated with the Russian vassal, which provided for the condition that he would carry out his political relations with other countries from Russia in agreement with the governor of Turkistan.

\section{CONCLUSION}

In conclusion, the research carried out in the years of independence of Uzbekistan differs from the literature created in the period before it in terms of ideology and coverage of history with objectivity, fairness.

The ban on the destruction of history during the Soviets caused this, as well as the censorship existing at that time, as well as the study of sources written by local historians.

In the years of independence, as a result of extensive use of resources and archive funds by historians, new views appeared in the study of the history of the Kokand Khanate, in particular.

\section{REFERENCES}

1. Ishquvatov V.T Diplomatic relations of Kokand-Russia in the history of the second half of the 20th century. History. candidate diss. Tashkent, 2004. 25 page

2. Bababekov H.N. Popular movements in the Kokand khanate and their socio-economic and political prepositions (XVIII - XIX centuries). Diss. History. sciences. Tashkent, 1991.Page.36

3. Topildiev N. The Kokand Khanate and the Russian Empire are at the crossroads of history. Tashkent: Academician, 2012. 76 page

†иёев X. Туркистонда Россия тажовузи ва хукмронлигига қарши кураш (XVIII-XX аср бошлари) Тошкент; Шарқ. 1998. 179-180-бб. 
4. Ziyoev H. Struggle against Russian aggression and domination in Turkestan (XVIII-early XX centuries) Tashkent; East. I'm sorry. 179-180-pages

5. Ilhamav Z. History of Amirlashkar. Tashkent: TSPU named after Nizami. It's 2008. 72-73PP.Omarov B, Alimov Sh. Fundamentals of spiritual and educational education in higher educational institutions. - T: "Science", 2004. 